] O U R A L O F

French and Francophone Philosophy
REVUE DE LA

philosophie française et de langue française

\title{
Bergson and the Morality of Uncertainty
}

Adriana Alfaro Altamirano

Journal of French and Francophone Philosophy - Revue de la philosophie française et de langue française, Vol XXIV, No 2 (2016) 41-61.

\author{
Vol XXIV, No 2 (2016) \\ ISSN 1936-6280 (print) \\ ISSN 2155-1162 (online) \\ DOI 10.5195/jffp.2016.770 \\ www.jffp.org
}

\section{(c) EY-NC-ND}

This work is licensed under a Creative Commons Attribution-Noncommercial-No Derivative Works 3.0 United States License.

\section{UILIS D-Sull}

This journal is operated by the University Library System of the University of Pittsburgh as part of its D-Scribe Digital Publishing Program, and is co-sponsored by the University of Pittsburgh Press 


\title{
Bergson and the Morality of Uncertainty
}

\author{
Adriana Alfaro Altamirano
}

Harvard University

\section{Introduction}

Moral and political theories, insofar as they are based on the finite and fragile life of human beings, incorporate or otherwise assume a reflection on the role of contingency in individual and collective pursuits. Even if often the goal is to curtail its effects, uncertainty always informs them in some way or another - whether in Plato's effort to arrange the political community and the life of the soul according to immutable and eternal ideas; in Hobbes' project to eliminate insecurity within the Leviathan; in Kant's rejection of any source of variability at the foundation of morals; or finally, in Rawls' proscription of luck in the overlapping consensus of justice.

According to Martha Nussbaum, however, any theory disposed to accommodate uncertainty will most surely have the virtue of acknowledging, as Aristotle did, two important truths: first, the centrality of action as an object of moral and political reflection, regardless of its always vulnerable character; second, that fragility and finitude not only threaten sociability and virtue, but constitute their very conditions of possibility as well. Perfection, universality, and the eternal thus lie beyond both the practical aims of ethics, and the normative aims of politics. ${ }^{1}$

Once we acknowledge the moral and political significance of uncertainty, making visible its close relation to action and sociability, we realize, however, that the question remains, how exactly do we understand or experience the fact of uncertainty? Does it simply mean that when we act there is no certainty regarding the future? In other words, is its meaning just a negative one: that we are not omniscient and omnipotent gods? Or, alternatively, is it something more substantial (a "positive name," as Hobbes would say), ${ }^{2}$ susceptible to multiple translations? Can uncertainty show us different faces, to which we would then react in different ways? If so, what is the meaning of such various possibilities for the exercise of agency?

Henri Bergson is best known for his reflections on time and memory, and for having developed a defense of free will based on an examination of 
our relation to our own past, and how it affects our capacity to act in the present: "We must, by a strong recoil of our personality on itself, gather up our past which is slipping away, in order to thrust it, compact and undivided, into a present which it will create by entering. Rare indeed are the moments when we are self-possessed to this extent: it is then that our actions are truly free." 3 Put very succinctly, freedom, for Bergson, is such "entrance" into the present: one in which we are capable of "synthetizing" our past - bringing it in, so to speak, in its entirety - in order to "create" the present as we act. 4 Thus, his project has been usually (and rightly) interpreted as a defense of freedom on what we can call a "retrospective" basis: his theory of time and memory, and of the latter's relation to matter, are intended to show that we are not determined by the past (hence its retrospective character).

However, the ways in which the prospect of the future and the fact of uncertainty affect our character as agents (and thus our capacity to be free) have been less assiduously explored. ${ }^{5}$ I want to undertake such a task here. As I hope to be able to show, Bergson's reflections on uncertainty, together with his insights on the phenomenology of human action, suggest a critical approach to the role of speculation and risk-management in contemporary societies, which is different to - although not necessarily incompatible with other critical perspectives, such as those coming from communitarians and post-structuralists.

While communitarians have given us reasons to be suspicious of the ways in which chance, risk, and uncertainty taint our institutions and our collective practices from the point of view of justice, Bergson's treatment and in this he is close to post-structuralism - brings out the ways in which our relation to uncertainty shapes our identity and our agency. Still, in contrast with the post-structuralist outlook, he is less concerned with developing resistance strategies in the face of power, and instead, invites us to consider the ways in which we can adapt, adjust, and make our agency more flexible in the face of unforeseen and changing circumstances.

For these purposes, I will turn, not to his early work on time and free will, but instead to the study of the modern belief in chance that he offers in his last book, The Two Sources of Morality and Religion, published originally in 1932, against nothing less than an immediate background of increasing political uncertainty in Europe and elsewhere. Bergson presents there his elucidation of the modern belief in chance as part of a debate about the differences between the so-called "primitive" and "civilized" mentalities - or, put differently, between the enchanted world of magic and the disenchanted world of science. ${ }^{6}$ For our purposes, one of the main arguments advanced in the book is that there is only one human nature underlying both kinds of mentalities, and therefore-the radical opposition between the two notwithstanding - that they are best interpreted as responding to similar anthropological conditions. ${ }^{7}$ 
One of the key anthropological conditions common to both mentalities is their respective susceptibility to the fact of uncertainty. In other words, both the primitive and the civilized mentalities have to develop strategies to cope with the series of challenges that uncertainty poses to action. The relevance of such strategies resides in that they constitute important pedagogical mechanisms in the exercise of human agency - strongly suggesting, therefore, that our relation to the future has, from a Bergsonian perspective, a very important role to play in the constitution of freedom in action.

Yet, since Bergson's own treatment in The Two Sources will not fully bring to light the point that I intend to investigate, I will resort to the French philosopher and poet Jean-Marie Guyau, and his reflections on what he calls "the love of risk." His work is especially pertinent, because, as we will see, Guyau's "love of risk" constitutes yet another way of dealing with the unexpected, which, on the one hand, amplifies agency-making it sharper and more assertive - and on the other, by the same token, ends up threatening it as well. Thus, the spectrum that opens up between Bergson's "belief in chance" and Guyau's "love of risk" nicely illustrates the moral stakes that human agency has in its relation to uncertainty.

Moreover, Guyau and Bergson were intellectually and biographically connected. Bergson, only four years younger than Guyau, was a student at the Lycée Condorcet, while the latter served there as a professor in 1876. In 1885, Guyau published a couple of articles offering a theory of time, which were later posthumously edited by Alfred Fouillée (his stepfather) with Bergson's help. Bergson himself published a review of the book in 1891.8 Guyau lived a short, and yet intellectually vigorous and passionate, life. He was a precocious and very prolific author - his first substantial investigation on utilitarianism (more than 1000 pages long) was written at age 20, and before dying at the age of 33, he published various books on aesthetics, morality, sociology, and education, in addition to poetry and some illustrated manuals of morals.

Even if Guyau remains a considerably obscure figure, especially outside of the French-speaking world, important studies of his thought have appeared as of late. These works show that in his own time, Guyau was meticulously studied by Durkheim, ${ }^{9}$ highly regarded by Nietzsche, ${ }^{10}$ and considerably influential for a good number of anarchists and artists. ${ }^{11}$ While the extent of Guyau's influence on Bergson has been adequately assessed, and their affinities on the topics of time and obligation already explored, 12 their respective treatments of risk and chance have not, to my knowledge, been contrasted yet. 


\section{The half-personal face of chance and its pedagogical value}

For a being endowed only with instinct, uncertainty does not exist. "An animal," says Bergson, "is sure of itself. In his case nothing intervenes between aim and act." 13 However, for a being that, besides instinct, possesses intelligence, a gap is soon opened between projects and outcomes, which discloses in turn the sole ground in which expectation, desire, fear, and hope can ever possibly grow. We call this gap "uncertainty." Thus, even if, on the one hand, we tend to think that intelligence reduces uncertainty through foresight, planning, and regulation, it is on the other hand true that without intelligence the problem of control would not even arise in the first place. Therefore, we are forced to admit, Bergson thinks, that intellectual activity is originally not what facilitates action by its command over nature, but what compromises it - to use his own words - by "introducing hesitation into it." 14

Intelligence itself will solve part of the problem, but there will always be left some margin of uncertainty, against which it remains powerless. In order to circumvent paralysis, nature endows the intelligent being with what Bergson calls "virtual instinct." This instinct will allow human beings, the intelligent species par excellence, to resist the discouragement in action that follows from the limits of rational insight into the future. ${ }^{15}$ But, what is this virtual instinct? And how does it provide the necessary impulse for movement?

According to Bergson, our capacity of fabulation performs precisely such instinctive function. ${ }^{16}$ Fabulation (la fonction fabulatrice), or our "mythmaking faculty" as it has been usually translated into English, is our capacity to create certain "phantasmic images" (images phantasmatiques), 17 which constitute a defensive reaction of nature "against the representation, by intelligence, of a depressing margin of the unexpected between the initiative taken and the effect desired."18

Fabulation, Bergson claims, is manifest in the so-called primitive societies, where the appeal to mystic causes is a regular practice. So, for example, if a beloved friend was killed in an accident, the primitive man will posit a mystic cause to explain the tragic event. Contesting Lucien LévyBruhl's interpretation of the phenomenon, Bergson says that the primitive man does not recur to mystic causes to explain every possible happening in the world, but rather only those which have a particular human significance. He concludes therefore that what the supernatural cause explains is never the physical effect, but its meaning.

For Bergson, the primitive man, without denying the operation of proximate causes, believes additionally that there is a "momentous fact" that remains to be explained: say, the death of a man. Bergson claims that there is nothing illogical, prelogical, or impervious to experience in such belief. ${ }^{19}$ The event surely pertains to a different ontological order, and therefore it is only 
appropriate for the man to look not just for any reason to explain it, but for an intention behind it.

Now, most importantly, in Bergson's view, evidence shows that the socalled civilized mentality is actually very close in this respect to the primitive one. While the former sees mystic causes operating everywhere, the latter sees chance at work all over the place. Those are prima facie opposite views: the one lives in an animated world, the latter in a mechanistic one. However, says Bergson, whenever the primitive man is reproached for not believing in chance, or even when it is simply stated that one of his characteristics is "not to believe in chance," the "civilized" man inevitably admits the existence of chance. 20 Of course, the "civilized" man will rejoin that he "admits" the existence of chance, only to the extent that it amounts to a negation of the animated world: chance is just a name for such refutation, and for the set of probabilities left in the absence of mystic causes; but properly speaking it is nothing. Nothing substantial, at least.

It is clear, Bergson concedes, that the civilized man does not make of chance a completely active force. Chance is certainly impersonal, but if it were a "mere nothing," he suggests, we would not even consider using the word. ${ }^{21}$ And indeed, Bergson thinks, in spite of all the civilizing elements that inform it, modern mentality will naturally glide into a more personal conception of chance. He gives the example of a roulette gambler who, by attributing his success or failure to good or bad luck, already conceives of chance in terms of a favorable or unfavorable intention. ${ }^{22}$ Thus, from being a purely mechanical outcome, the event is transformed so as to be of human significance.

Certainly, the gambler is completely capable of explaining the result by appealing to natural causes (the force with which the roulette was turned, the weight of the ball, etc.); but when, on top of that, the thought crosses his mind that "it was good/bad luck," he is, according to Bergson, already "objectifying his will to win, and the resistance to this will [...] in order to feel the presence of a hostile or friendly power, and thus give its full interest to the game." 23 Luck, therefore, interestingly resembles the mystic cause. This proves, our author thinks, "the kinship of this spontaneous intelligence with the primitive mentality": "Scratch the surface, abolish everything we owe to an education which is perpetual and unceasing, and you find in the depth of our nature primitive humanity, or something very near it." 24

Provided we distinguish in the primitive mind between the faculty for myth, on the one hand, and full-fledged mythology, taboos, and magic (in sum, primitive religion), on the other, this kinship will easily become apparent. While primitive religions are, according to Bergson, only late products, and even fixations and distortions of the initial impulse that gave rise to them, the fabulation faculty is their original force. This initial impulse is the source of indeterminate forces, which oscillate around the physical and the moral, orienting human action accordingly. ${ }^{25}$ Bergson speculates, for 
instance, that even if taboos ended up being associated with particular things or places, this must have been a late solidification of what was originally a "naked prohibition," that is, a sheer force that resists and pushes against certain actions. ${ }^{26}$ Concrete taboos are the end-point of a force expressed in fabulation, which "before it completed its work" in primitive societies, it must have yielded "many prohibitions which are semi-physical, semi-moral restraints on certain individual acts." 27

Bergson's analysis reveals that modern people do orient themselves in a similar fashion, by way of appealing to semi-impersonal forces. He argues, for example, that the sight of a sign-board saying "Trespassers will be prosecuted" makes us perceive first of all the sheer prohibition as a resistance to our will, whereas only later we "have the vision of the constable lying in wait to report us." 28 Building on contemporary child-psychology research, he explains that the child who knocks his head against a table and then hits the table back, is not simply venting his anger on the table, or mistakenly thinking that the table is a person who struck him. "The truth is that between the identification of the table with a person and the perception of the table as an inanimate object, there lies an intermediate representation which is neither that of a thing nor of a person." 29 What the child perceives is the action of striking, the intention to hit; the table as an object is an accessory to the perception.

Bergson offers two more truly remarkable examples: William James' description of his experience during the San Francisco earthquake of 1906, in which he had the "irresistible perception" of facing such natural phenomenon as "a living agent," 30 and Bergson's own report of his reaction to the 1914 French war declaration, when he felt struck by the rather concrete character of the threat - that is, when a set of initially dispersed actions and events came together and, suddenly acquiring almost a personality of their own, formed that which we would eventually call World War I. ${ }^{31}$

Now, the crucial point to recall here is that, for Bergson, human beings share the ambiguous character of the forces that they take themselves to be surrounded by, such as the mystic cause, the figure of chance or luck, the war, and the earthquake. Their ambiguity resides in that, as conscious beings that exist in both time and space, they always do two things. On the one hand, in trying to remain true to perception, they attune themselves to the heterogeneity of the so-called vital impulse, present both in the flux-like character of their inner life (inner perception), as well as in the manifold of sensations that they receive from all over (outer perception). On the other hand, however, insofar as they are agents-i.e., bodies moving in space-they must always "translate" the dense heterogeneity of perception into distinct and clear-cut, even if interconnected, actions. ${ }^{32}$ Such dual condition - constituted both by the density of the vital-impulse and the discrete requirements of action makes human agency something that is not fully delineated, but that still somehow stands out from the continuity of the given. And indeed, Bergson's 
phenomenology of action and perception confirms such parallelism in yet another, more striking, way.

According to him, agency and reality are "peers" engaged, so to speak, in dialogue and joint action. For instance, according to Bergson, "concepts are questions that we ask to reality, from a practical point of view, regarding the attitude that we should take toward her, or the attitude that she takes toward us."33 Likewise, what we perceive of reality "poses a question to our agency," 34 and therefore, any given fact is always an adaptation of reality to the interests of practice.

Moreover, this dialogue is a fluid exchange, in which clearly defined concepts and neatly-defined bodies come only secondarily, as we saw in the example of the child and the table. Or consider the fencer-one more of Bergson's examples - who, in order to lunge properly - that is, in order to adequately anticipate and react to the reality that confronts him - "knows that it is the movement of the point which has drawn the foil [of his adversary] forward, that it is the foil that has drawn the arm forward, [and] that it is the arm that stretched out the body by stretching out itself." 35 In sum, in our dealings with reality, perception of movement, as a datum of experience to which we respond in action, has preeminence over the perception of fixed matter, and over the production of clear-cut concepts. Therefore, for Bergson, there is an original way of relating to the world as agents: flexibly and intuitively. Agents - both human and non-human, although in different ways - are susceptible to "the call of reality," which urges them to meet it in its own (ambiguous) terms. ${ }^{36}$

And yet, as we know, the paradigm of moral action in modernity often requires otherwise: it is based on the rigidity - to be sure not of matter - but of reason and conceptual clarity. Action is considered moral only when it is autonomous - completely voluntary and consciously endorsed, with no place for unreflective habit or improvisation. Thus, moral theory establishes a wellknown dichotomy: it reduces all possible activity to absolute voluntarism, on the one hand, and absolute automatism, on the other. For Bergson, however, this places inappropriate demands for moral agency: it requires us to make fully conscious decisions at every moment, supposing therefore, an almost omnipotent will.

Worse still, such demands are not just mistakes attributable to some lack of insight on the part of modern philosophers, but rather have their very root in intelligence's natural tendency to, as Bergson says, solidify flexibility into categories. ${ }^{37}$ Given this powerful tendency, I think, our ability to attune ourselves to the original vagueness of agency should not be taken for granted. We must learn how to do so. Therefore, we need a model of what non-fully voluntary activity should look like.

Bergson's account suggests that the semi-personal forces that "escort" human agency perform exactly that pedagogical function, serving us in more 
than one way: they not only provide consolation in the face of frustration and disappointment, as Bergson himself explicitly maintains in The Two Sources, but offer a "mirror" as well on which to reflect and shape our own agency a conclusion that, moreover, seems warranted, I think, by his phenomenology of action, as we have just reviewed it. ${ }^{38}$ In other words, the virtual instinct of our myth-making faculty shows us a bridge or a compromise between, voluntary and distinctly personal action, and dead matter subject to blind necessity. And in doing so, it "trains" us to better deal with uncertainty.

Let us put it this way: uncertainty "offends" a completely defined and established personality, for which only the categorical will suffice. On the contrary, contingency is not necessarily an embarrassing match for what remains supple and unfinished anyway. As we come to acknowledge nonfully voluntary or semi-automatic activity in the world, we grasp a deflated and more flexible version of our own will. Again, this virtual instinct "coaches" us not only by encouraging action in the face of the depressing margin between our expectations and an eventual failure, but also, I think, by enabling us to take advantage of unforeseen opportunities and happy fortuities.

Thus, by transforming occurrences "into an Event, which resembles a human being," the myth-making faculty establishes, as Bergson says, "a certain comradeship" between my circumstance and myself, which in itself carries great pedagogical value. ${ }^{39}$ Therefore, we come to see that while, for Bergson, the way in which we relate to our past is central to elucidate the meaning freedom, his account of action shows that a certain relation to the future-and, consequently, to uncertainty - plays a paramount role as well.

\section{The belief in chance and superstition}

Like I said before, according to Bergson, primitive religions are a late development of what started off as an original and healthy tendency to identify semi-personal forces in the outside world. Such a tendency, however, often gets out of control: following a "logic of absurdity," "primitive" religion endlessly piles up one superstition over another, "lead[ing] the mind even further and further astray towards wilder and wilder consequences." 40 As Frédéric Keck explains, these religions are according to Bergson "a sign of a morbid tendency, the human tendency to think without acting, a form of collective dream or hallucination." 41 The mind embarks on an imaginative race, by which the once healthy myth-making faculty engages in an hallucinatory multiplication of absurdities, without any scruple about the intellectual superiority of its inventions. ${ }^{42}$

However, notice that this tendency, even if it ends up in the realm of the irrational, the absurd, and even the monstrous, is not in itself foreign to intelligence. As Bergson writes, "An essentially intelligent being is naturally 
superstitious, and [...] intelligent creatures are the only superstitious beings." 43 Moreover, since, as we saw, "The intelligence of primitive peoples is not essentially different from our own; [both have a tendency] to convert the dynamic into the static, and solidify actions into things," 44 this superstitious inclination should be present in both primitive and civilized mentalities.

If this is so, then the question is: what would such a tendency look like in the civilized context? If in primitive religion, the myth-making faculty "fashion[s], out of the elementary personalities looming up at the outset, gods that assume more and more exalted form like those of mythology," 45 what kind of god-like figure can be fashioned out of the belief in chance? As we saw before, due to our myth-making faculty, the belief in chance already takes the form of the semi-personal force of luck. But then, again, the question is: what would it mean for our belief in chance to take one more step forward, and transmogrify into an absurd "collective dream or hallucination," as it is pulled by the corrupting influence of a hypertrophic imagination and an intelligence that solidifies action, and "converts the dynamic into the static"?

Bergson does discuss cases of superstition in the civilized world, and we have already reviewed some of his examples of our tendency to personify events (James and the earthquake, Bergson and the war, the child and the table). But Bergson's The Two Sources lacks a more sustained reflection, parallel to that on primitive religion, about the morbid proclivities of the reification of chance, when it is aggravated and exaggerated along the lines of superstition in the primitive mentality. The reason, I think, why Bergson is not interested in that question is simply that in The Two Sources he has a very different agenda - namely, exploring what he calls "open morality." After all, a crucial purpose of the book is to examine the "leap" that is required to arrive from the closed to the open perspective on morality and sociability. And, to be sure, the "insurance device" against the type of contingency specific to the open sphere will not be some corrupt version of chance, but on the contrary, the mystical confidence that "lifts the soul to another plane," "ensur[ing] for [it] to a preeminent degree, the security and the serenity which is the function of the static religion to provide." 46 However, as Bergson himself admits, "true mysticism is rare." 47 Thus, we cannot generally expect to see the confidence that bolsters the mystic feeling of humanity. Rather, more often than not, the believer in chance, by "the very application of intelligence to life open[s] the door to the unforeseen and let[s] in the feeling of risk." 48

\section{The twin brother of chance}

As we have seen already, in Bergson's account, chance lies on the border between the personal and the impersonal. "Chance is mechanism as though possessing an intention," or "an intention emptied of its content." 49 In contrast, by the "feeling of risk" I will denote here the civilized mind's relation 
to uncertainty, as it yields to the tendency to reify the semi-personal force of luck, looking in it for an increasingly more definite "counterpart." 50

Just as, for Bergson, the belief in mystic causes and the belief in chance (either in the form of good or bad luck) are analogous, in that they are both products of our myth-making faculty, I understand the feeling of risk as being analogous to the belief in the "extravagant gods of mythology." To put it in Roman terms, risk is chance when it is not anymore simply an appeal to good or bad luck, but the full-fledged goddess Fortuna.

As we will see, compared to chance's wink, risk's appeal is much more unequivocal. While chance asks us to acknowledge the existence of regularities that can be measured and predicted, risk-the "wild" twin brother of chance-always elicits our love or our aversion. It has a more defined face, and it asks for a more definite gesture. ${ }^{51}$

In turning to Jean-Marie Guyau's reflections on the "love of risk," and in order to better appreciate the extent to which they are pertinent here, I will first review the overlap between his and Bergson's respective theories of obligation. ${ }^{52}$ Guyau, like Bergson, rejects both rationalist and sentimentalist accounts of duty. Both authors share an ontological conviction that there is something, beyond both reason and emotions, which ultimately accounts for it. This "something" is directly related in both cases to action and movement.

As we learn in the very first page of the book, the general project of The Two Sources is to "discover [the] deeper sources of our moral feelings" 53 and to explain "how a moral motive can have a hold upon the souls of men." 54 According to Bergson, no theory of moral obligation in terms of reason or sentiments is possible. Just as the most we can do with gravity is devise a formula to figure out velocity and acceleration, without entertaining the hope of "explaining it away" by appealing to elements beyond the force it exerts, Bergson claims that we can build systems of duties that explain why we must do $\mathrm{x}$ or $\mathrm{y}$, but no theorization of it, as a phenomenon, will follow in terms other than itself as a force of nature. Reason intervenes by regulating, but it cannot push us to action. Sentiments might solve part of the problem, but they do not explain why we have to regulate them in the first place. If obligation could speak, Bergson says, it would only articulate the following words: "You must because you must." 55 Given this, he thinks that the only way to scrutinize obligation is not to look for its cause, but rather to recur to phenomena that present similar effects.

Thus, Bergson turns to instances that, like obligation, produce or motivate actions: instincts in animals, and habits in men. That is actually why he turns to our myth-making faculty as well: it is similar to duty because its effects (i.e., the belief in mystic causes and the belief in chance) are forces that exert pressure on acting beings that-to put it in Kantian terms - do not pertain only to the noumenal, but also to the phenomenal world. 
For his part, in A Sketch of Morality without Obligation or Sanction, Guyau argues that morality should be looked for in action, in "a kind of natural power, preceding knowledge-a power which impels us to act and to produce." 56 Just as Bergson declared moral conscience to be the pressure of obligation "as weighing on the will like a habit, each obligation dragging behind it the accumulated mass of [all] the others," 57 for Guyau duty is a fact "imposing itself on consciousness as a superior force." 58 From this shared set of insights, it follows that their strategy to study obligation will look very much alike. ${ }^{59}$ And indeed, Guyau asserts we must "try to clearly show this fact [of obligation] in its essential variations, and in its relations with other similar facts of consciousness." 60 Thus, correspondingly to Bergson's search for phenomena with analogous effects to those of obligation, Guyau sets out to look for "admissible 'equivalents' or 'substitutes' of duty." 61

Among the suitable equivalents of duty, Guyau identifies "the love of risk in action and of struggle." 62 Both rationalists and hedonists, he claims, consider moral dilemmas as if the uncertainty of the outcomes could be somehow overcome. ${ }^{63}$ Instead, his treatment makes manifest that the love of risk should be much more than just a disposition that can "vary" without substantially affecting agency itself, as economists assume in the notions of high or low risk-aversion. In microeconomic theory, our disposition towards risk is just one more datum in the agent's "given preferences." In Guyau's picture, instead, the love of risk is more than just a preference: it concerns the agent's moral capacity itself. 64

Let us analyze more closely what this means. Guyau explores uncertainty as it is experienced by the agent. He acknowledges at the outset that the pleasure of victory and conquest tinge to a great extent the lure exerted by them. ${ }^{65}$ For that reason, he says, we find clear expressions of the love of risk in professions such as the soldier, the huntsman, the traveler, the colonist, the medical doctor, and even the engineer.

That being said, he notices that victory, as the positive outcome of a risky undertaking, is merely one element among others that mark more deeply its moral meaning. At stake is not only victory, but also one's deeds. Risk - as either danger or opportunity-implies a challenge, a call to action, which requires a disposition for adventure: "In calculating we must not take into account only good and bad chances, but also the pleasure of running these chances." 66 In other words, risk lets us become aware of our character as agents. Moreover, this awareness varies depending on the character of the opponent. We can be confronted, he explains, to other human beings in war, or to animals in hunting. We then identify ourselves as soldiers or hunters, respectively. We can also be challenged by nature or by objects, as the sailor who wrestles with the sea, the hiker with the mountain, the employee with a concrete task (and, we shall add, the writer with the blank page). Furthermore, we can resist the assault of "faceless" or impersonal enemies, like the patient who fights a mortal illness, ${ }^{67}$ the investor who struggles with 
a volatile and capricious financial world, or any "fighter in life" facing "difficulties of all sorts to be conquered." 68 Notice that in all the cases described by Guyau, risk - unlike chance-provides a much more personal epistemological compass: it defines both events and defines our identity more thoroughly.

It is undeniable that in Guyau there is something of an "ethics of danger and adventure," potentially implying that "the more intrepid, the more excellent." He is certainly closer to Nietzsche than Bergson ever was. Still, I do not think that a straightforward invitation to boldness constitutes Guyau's main epistemological insight here. As I see it, the point is not that those who are more prone to adventure feel more alive than people who are risk-averse, being therefore capable of superior action. ${ }^{69}$ Rather, the point is that, no matter if we pursue or avoid it, risk lets us feel our life, and allows us to become aware of its value. Being tempted by risk means being challenged by it, regardless of your "revealed preferences" on that respect. 70

Guyau indicates, furthermore, that "[t]o the pleasure of risk is often added that of responsibility." 71 For Guyau, risk is all the more thrilling when it combines adventure and gravity. To put it in Kantian terms, risk is sublime when it involves something that commands respect. However, notice the difference between the sublimity of risk in Guyau, and the sublimity of the law in Kant. Guyau's risk involves not only the presence of a lofty goal or principle, but also the momentousness of being, there and then, accountable for it. What matters is the weightiness of undertaking the risk necessary for the achievement of a certain goal or for the actualization of a certain principle. Put differently, Guyau's "love of risk" is analogous to Kantian respect, but with agency added. The "divinely great tension of mind and feelings" that we experience when confronted by risk is sublime only as it combines loftiness with the sense that it depends on $u .^{72}$

Guyau's examination of the "experience of risk" in the light of Bergson's reflections on "the belief in chance" suggests several points. First, both constitute two different ways of dealing with the unexpected-the latter moderate, the former extreme; and, second, relatedly, they are both analogous to duty or obligation. Risk, however, as we have seen, indicates the way toward an always-latent distortion of the civilized mind as it relates to uncertainty. Risk has an extraordinary capacity to summon our agency in a way a simple "number indicating the odds" would not. It produces a distortion, I think, because - independently of whether we are risk-takers or risk-averse-risk presents an appeal that strikes us as urgent, capable of blinding us to all other concerns. 


\section{The ambiguities of risk}

Guyau claims that our struggles (either with war, nature, illness, or difficulties in general) all share the character of the passionate duel: "In truth, he says, the doctor who starts for Senegal has decided upon a kind of duel with the yellow fever."73 And indeed, the metaphor of the duel illustrates very well why "the love of risk" is a useful antidote for the shortcomings of the impersonal "belief in chance." Since the fight will define the identity and the future of the fighters, there is no way in which the duelist could not take it as something personal. Again, risk sharpens our agency and defines our identity, and those might be good things. However, the history of dueling presents interesting transformations that hint, in turn, at the moral ambiguities of the "love of risk."

The passionate duel finds its ancestor in the judicial duel of the Middle Ages, which was a procedure used to settle accusations in cases where there was no other evidence available, such as witnesses or a confession of one of the parts. The parts involved would engage in a single combat, and the assumption was that God would reveal his will in the outcome. In that sense, the judicial duel was not supposed to be really a contest between two adversaries, but only the occasion for God to communicate the truth. The significance of the combat derived not from action but from knowledge; and victory did not really mean greatness, but goodness.

Whereas the judicial duel had at its center the discovery of truth, during its historical transformations in the late 19th- and early 20th-century it came to be seen not only as an instance of pernicious and uncivil violence, but mainly as something absurd: a mere display of narcissistic and megalomaniac tendencies. Conrad's short story The duelists illustrates this folly: the contenders have repeatedly fought each other for a lifetime, but none of them really knows anymore why they both keep doing it, nor the original basis of their enmity. The only motive that pushes them into fighting each other over and over is pure vainglory combined with imprudence. ${ }^{74}$

Exploring further Guyau's suggestion to model our attitudes toward the struggles of life after the paradigm provided by the passionate duel, it is interesting to note that the duel-whether in its medieval or its modern version - represents, as an institution, a way of dealing with uncertainty. The judicial duel was supposed to be a medium for truth in the face of uncertainty (who is responsible for this crime?); on the other, the passionate duel also seeks some kind of certitude in a given conflict between two adversaries (who is the best-the more courageous, the more honorable-among the opponents?). While in the judicial duel it was innocence what was in doubt, the passionate duel is meant to prove the courage and honor of the rivals in question. In the former case, the combat was a medium for the revelation of a higher truth, while in the latter, it is the direct test of a mundane one. 
Now, this transformation in the history of dueling suggests that the moral purchase which Guyau wants to draw from the latter might not be as unproblematic as he seems to take it is. The duelist attitude that he identifies as the paragon of moral agency might be closer to the vanity of the boastful man than to the important task of seeking truth and delivering justice. In the judicial duel, the legitimacy of the result came from (divine) knowledge, while in the passionate one, it comes from mere force, usually motivated by effrontery or, even worse, by domineering impulses.

If indeed the love of risk partakes in character with the passionate duel, then perhaps the only relation with uncertainty that this experience can offer to the modern mind dangerously oscillates between truth and absurdity, justice and force, meaning and meaninglessness. Thus, it is not clear the extent to which the love of risk can in fact be a good substitute for the moral shortcomings of the belief in chance: it might be able to make up for the frustratingly impersonal character of the latter, offering in principle an arena in which to exercise agency more assertively. But then, paradoxically, by exposing our agency in all its empowerment and all its vulnerability at the same time (i.e., displaying uncertainty in all its magnitude), the feeling of risk has very often left us with a well-known dilemma - a grim one, indeed, which can be seen most clearly, I think, in the field of politics.

Whenever risk, contingency, and insecurity are given a preeminent focus in political thought - when they are turned into the main problems to be addressed - we are usually left with two options: either total insurance against risk at the cost of liberty (think of Hobbes' Leviathan), or the absurdity of experiencing risk for the mere joy of it (the "intoxication with danger," as Guyau calls it, illustrated by the extolment of - or at least the compliance with - violence in different versions of nationalism, colonialism, capitalism, and terrorism, and displayed by a number of adventurers in politics, war, and finance). ${ }^{75}$ I understand this dilemma as the instability of agency: it shows the difficulty of achieving a "middle ground" in our dealings with uncertainty, that neither stultifies agency by reducing it pure obedience, nor distends it through megalomania or recklessness.

\section{Conclusion}

As I said before, beginning with Plato, uncertainty has always informed moral and political theories in some way or another. More recently, Michael Sandel has articulated a communitarian attack against the legitimacy that speculation has acquired in contemporary economic systems. ${ }^{76}$ The claim is that speculation has corroded the values that we presumably uphold in the legal and political spheres, as distinctive of the way of life that the people living in constitutional democracies collectively endorse. 
In today's global capitalism, he explains, "People increasingly make money, not by producing goods and providing services, but by managing risk."77 Practices that have become regular-such as purchasing death insurance for employees, for very sick or old people, or even for complete strangers - show the extent to which the world of finance feeds on the "speculation on life and death." This is troubling because "an ethic of speculation [is] corrosive of moral and civic norms worth caring about." 78

Others, from a more Foucauldian perspective, have explained how the power-dynamics in which subjectivities are produced in society (what is known as "governmentality") fosters, in neoliberal contexts, a subjugating attitude of boldness and audacity in the face of risk, under the banner of a particular work ethic and a rhetoric of self-responsibility. Thus, for instance, "discourse[s] on fiscal self-realization extolling the virtues of entrepreneurship and voluntarism as a personal ethic" really instantiate a framework of oppression, in which people are enjoined to fulfill an ideal in which risks should be fearlessly tamed, and uncertainty courageously faced. ${ }^{79}$ As a response, for example, one critic has suggested that procrastination can be endorsed as a resistance strategy, even if it represents "just one opening into the wider question of the contemporary practice of temporal counterconduct within the context of neoliberal governmentality." 80

Rather than viewing the love of risk as a corroding practice in which speculation bets on the life and death of other people, or as a the epitome of "the production of the neoliberal subject as a self-producing subject," 81 following Bergson and Guyau, we see that, anthropologically speaking, our relation to uncertainty "naturally" displays a wide spectrum that allows for more or less assertive way of addressing it-or rather, to put it in a more Bergsonian fashion, a spectrum that allows for a more or less assertive way of letting us be addressed by it. ${ }^{82}$

As we have seen, there are advantages and disadvantages of the different positions in such a spectrum. Guyau's analysis of the love of risk shows that a more voluntaristic way of relating to uncertainty might have the advantage of boosting agency, by giving us a more defined identity, enhancing our sense of responsibility or momentousness, and bringing forward the feeling of hope. However, Guyau's analysis suggests that the love of risk presents a tendency towards polarization as well: just as in primitive religion superstition proliferated, gravitating towards the absurd and the monstrous, we tend to "dramatize" uncertainty, through the pressing injunction to take on challenges and risks, in the personal, professional, political spheres. ${ }^{83}$

The phenomenological bridge between the belief in chance and the feeling of risk that I have traced here, shows two things. First, that the tendency to replace the former with the latter-what I have called the dramatization of uncertainty - is rooted in our anthropological condition. In 
other words, independently of the current capitalistic and neoliberal context, the love of risk is an ever-present human possibility - one which, moreover, has advantages and disadvantages of its own. Second, with Bergson, we explored the pedagogical purchase of the more moderate attitude toward uncertainty expressed in the belief in chance. In my interpretation, for Bergson - and in contrast to a criticism of speculation from a communitarian perspective that seeks to defend a set of shared ethical values, and to a more Foucauldian denunciation of risk-taking attitudes as a strategy of resistance within social power-structures - the virtues of such moderate attitude have to do, as we saw, with the proper cultivation of human agency.

We saw, for example, that by way of an appeal to luck, events acquire a status that "matches" our capacity to have some influence in them. This gives us the occasion of asserting our agency, but without assuming omnipotence or complete control, and therefore it represents a moderate way of relating to the uncertainty of the future. Given that luck is "a semi-voluntary choice that may serve as a counterpart to [one's] own [choice]," 84 it seems to provide, at least in principle, some check to an inflated notion of the will. Thus, the belief in chance becomes a model for our own agency, if we follow Bergson in his account of the latter. On this score, Bergson rejects a fixed personal identity in favor of one capable of relying on both habit and improvisation. This kind of personality has the advantage, regarding uncertainty, of giving us resources for accepting challenges and taking risks, without expecting to be in complete control of an envisaged plan, nor putting our whole identity at stake. With its help, we would be able to accept the dictates of fortune, and deal with them both through the solidity of routine and the grace of spontaneity.

While Bergson is famous for having articulated an account of agency in which freedom is made possible through a particular relation to our past, the relevance of uncertainty for action, as we have seen here, makes it clear that our relation to the future is significant for a Bergsonian understanding of freedom as well. From that perspective, we do not approach the self from the side of memory, but rather, focus on its character as a "moving body," capable - as Bergson says - of answering to reality "with a yes or a no," depending on what the circumstances require. 85 In that sense, in contrast to the Kantian notion of the autonomous subject, as well as in contrast to a Guyauian/Nietzschean risk-lover Übermensch, Bergson offers a more modest, but also more versatile, notion of free agency in the face of uncertainty. 
${ }^{1}$ Martha C. Nussbaum, The Fragility of Goodness: Luck and Ethics in Greek Tragedy and Philosophy (New York: Cambridge University Press, 2001), $290 \mathrm{ff}$.

2 Thomas Hobbes, Leviathan, reprinted from the ed. of 1651 with an essay by W.G. Pogson Smith (Oxford: Clarendon Press, 1909), ch. IV, 30.

${ }^{3}$ Henri Bergson, Creative Evolution, trans. Arthur Mitchell (New York: H. Holt, 1911), 200.

${ }^{4}$ Bergson illustrated the coexistence of the past and the present through his famous "cone-metaphor": we stand at the apex of this inverted cone, which, in turn, represents the constant accumulation of the past. At each one of its levels we find the totality of the past, but at different degrees of contraction or expansion. In other words, the cone displays different levels of consciousness, at which we experience different ways of relating to our past. For Bergson, one could say, freedom is gained by "delving into" this cone, exploring the multiple ways in which we can traverse its different levels (see Henri Bergson, Matter and Memory, trans. by Nancy Margaret Paul and William Scott Palmer (New York: Macmillan, 1912), ch. III, esp. sections "Relation of past and present," and “Memory and general ideas," 190-212).

${ }^{5}$ Although see, for instance, the work by Frédéric Keck, which I have found particularly useful (see infra section "The belief in chance and superstition").

6 Bergson normally uses scare quotes for the terms "primitive" and "civilized," most probably in consonance with his claim that both mentalities are fundamentally the same. Having said this, I will not use scare quotes for these terms in the rest of the article.

${ }^{7}$ That is one of Bergson's main contentions against the anthropologist Lucien Lévy-Bruhl.

8 See John A. Michon, “Jean-Marie Guyau (1854-1888)," in Guyau and the idea of time, ed. John A. Michon et al. (Amsterdam: Elsevier, 1988), 19-36, and Jordi Riba, La Moral Anomique de JeanMarie Guyau (Paris: Harmattan, 1999), 21-32.

9 See Émile Durkheim, “L'irréligion de l'avenir, étude de sociologie (Book Review)," Revue Philosophique de la France et de l'Étranger 23 (1887): 299-311. For comparative assessments of the two authors see Michael Behrent, "Le débat Guyau-Durkheim sur la théorie sociologique de la religion. Une nouvelle querelle des universaux?," Archives de sciences sociales des religions 142 (2008): 9-26, and Marco Orru, "The Ethics of Anomie: Jean Marie Guyau and Émile Durkheim," The British Journal of Sociology 34 (1983): 499-518, where the author claims that Durkheim took the term "anomie" from Guyau, and then transformed it to fit his own approach.

10 See Ilse Walther-Dulk, "Regard sur la réception de Guyau par Nietzsche à la lumière de ses annotations sur L'irréligion de l'avenir," in L'effet Guyau : de Nietzsche aux anarchists, ed. Jordi Riba (Paris: Harmattan, 2014), 7-16, and Keith Ansell-Pearson, "Contra Kant and Beyond Nietzsche: Naturalizing Ethics in the Work of Jean-Marie Guyau," Hegel Bulletin 35 (2014): 185203.

11 Among them, most famously, Kropotkin. See Geoffrey C. Fidler, "On Jean-Marie Guyau, Immoraliste," Journal of the History of Ideas 55 (1994): 75-97.

12 See, for example, Vladimir Jankélévitch, “Deux Philosophes de La Vie Bergson, Guyau," Revue Philosophique de La France et de l'Étranger 97 (1924): 402-49; Keith Ansell-Pearson, “Morality and the Philosophy of Life in Guyau and Bergson," Continental Philosophy Review 47 (2014) : 5985; Jordi Riba, La Moral Anomique de Jean-Marie Guyau; and Renzo Ragghianti, “Décomposer un texte: La genèse de l'idée de temps de Guyau," in Guyau, Jean-Marie, La mémoire et l'idée de 
temps: édition critique de la genèse de l'idée de temps, ed. Alfred Fouillée (Paris: Harmattan, 2011).

${ }^{13}$ Henri Bergson, The Two Sources of Morality and Religion, trans. R. Ashley Audra and Cloudesley Brereton, with the assistance of W. Horsfall Carter (Notre Dame: University of Notre Dame Press, 1977), 139.

${ }^{14}$ Henri Bergson, Time and Free Will: An Essay on The Immediate Data of Consciousness, trans. F.L. Pogson (London: G. Allen \& Co., 1913), 177-179.

${ }^{15}$ Bergson, The Two Sources, 152.

${ }^{16}$ As can be noted, Bergson's method is teleological: by asking what could the function of our mythmaking faculty possibly be, he is attributing an "intention" to nature. I cannot examine Bergson's methodological apparatus on this point more thoroughly here, but suffice it to say, for the sake of exonerating him of crude teleologism, that he declares to be using the notion of "intention of nature" as a metaphor (Bergson, The Two Sources, 110). On this topic, see Étienne Gilson, From Aristotle to Darwin and Back Again: A Journey in Final Causality, Species, and Evolution (Notre Dame: University of Notre Dame Press, 1984), 90-104.

${ }^{17}$ Bergson, The Two Sources, 110.

18 Ibid., 140.

19 Ibid., 145.

${ }^{20}$ Ibid., 147.

${ }^{21}$ Ibid., 147.

22 Ibid., 145.

23 Ibid., 146.

24 Ibid., 127.

${ }^{25}$ Ibid., 126-29.

26 Ibid., 126.

27 Ibid., 126.

28 Ibid., 126.

29 Ibid., 125.

30 Ibid., 153-57.

${ }^{31}$ Ibid., 159-60.

32 See Henri Bergson, Histoire de l'idée de temps: cours au collège de France: 1902-1903 (Paris: Presses Universitaires de France, 2016), 53-85; and Matter and Memory, ch. I.

${ }^{33}$ Bergson, Histoire, 73. My translation; my emphases.

${ }^{34}$ See Bergson, Matter and Memory, 40-41.

${ }^{35}$ Bergson, The Two Sources, 104.

${ }^{36}$ See, Bergson, Histoire, sessions 3 and 4.

${ }^{37}$ Bergson, The Two Sources, 128. 
38 On this notion of "escorting," see Bergson, Histoire, 71, where he says that different stimuli "accompany" (accompagner) and "demand" (exiger) analogous reactions on our part.

39 Bergson, The Two Sources, 157.

40 lbid., 137.

${ }^{41}$ Frédéric Keck, "The Virtual, the Symbolic, and the Actual in Bergsonian Philosophy and Durkheimian Sociology,” MLN 120 (2005): 1142. My emphasis.

42 On the difference between fabulation as a legitimate "faculty of the mind," capable of "creating personalities whose stories we relate to ourselves," and imagination as a morbid tendency to invent without intellectual scruple, see Bergson, The Two Sources, 195.

${ }^{43}$ Bergson, The Two Sources, 109. As Keck notes, for Bergson, "religion is first an intelligent reaction to a specific situation through adequate affects, but it then becomes a generalized fear of nonidentified threats, which can be called superstition.” (Keck, Ibid.,1141, my emphasis).

${ }^{44}$ Bergson, The Two Sources, 128.

45 lbid., 164-65.

46 Very briefly, for Bergson, the commitment to equality and humanity characteristic of open morality is not based on reason but rather on intuition. The embrace of humanity as a whole is based, in his view, on a creative emotion that is not arrived at by simply logically extending our particularistic moral relations - the tribe, the family, the community, or the nation-state - but through a qualitative leap from the closed to the open, made possible only by the moral creativity of some visionary figures. See Alexandre Lefebvre, Human Rights as a Way of Life: on Bergson's Political Philosophy (Stanford: Stanford University Press, 2013); Richard Vernon, “Bergson's Two Sources Revisited: The Moral Possibility of Nationalism," Contemporary Political Theory 2 (2003): 271-88; and Paulina Ochoa Espejo, "Creative Freedom. Henri Bergson and Democratic Theory," in Bergson, Politics, and Religion, ed. Alexandre Lefebvre and Melanie White (Durham: Duke University Press, 2013).

47 Bergson, The Two Sources, 213.

48 Ibid., 138-39. In his work, Keck contrasts the different kinds of assurance provided by static (primitive) religion, on the one hand, and by dynamic religion (the religion of humanity), on the other: in the former, we have the primitive story-teller obtaining assurance through the identification of mystic causes operating behind events; in the latter, we have the mystic's confidence that intuits the totality of humanity, "which does not need any materiality to manifest itself” (Frédéric Keck, "Assurance and Confidence in The Two Sources of Morality and Religion," in Bergson, Politics, and Religion; and see also, by the same author, "Bergson dans la societé du risqué," in Lire Bergson, ed. Frédéric Worms and Camille Riquier (Paris: Presses Universitaires de France 2011)). I see two differences between Keck's treatment and what I am trying to do here. First, I compare the assurance provided by primitive religion (same as Keck), not with the mystic's confidence, but with the assurance established by the modern belief in chance, and its trust in regularities. Second, I am trying to understand the significance of such a contrast, not for belief or intelligibility, but for action. However, I have found his work illuminating and reassuring.

49 Bergson, The Two Sources, 148-9.

50 To clarify, the notion of "risk" in its current usage in the social sciences immediately suggests the possibility of quantification. As it will become clear shortly, this is not the connotation that I want to attribute to the word. On the other hand, "chance" is meant here to indicate the regularities that are captured and studied by statistics-which are, nonetheless, the necessary counterpart for anything to be random and fortuitous. Thanks to Christine Zabel, for helping me to clarify this point. 
51 Keck observes as well the link between "intentionality" and "personality" in Bergson's account of the myth-making faculty (Keck, “Assurance and Confidence in The Two Sources," 274).

52 While Bergson's model of the closed society in The Two Sources follows Durkheim for the most part, his reflections on the force of obligation ostensibly coincide with Guyau's. For comparative treatments between both authors see Keith Ansell-Pearson, "Morality and the philosophy of life in Guyau and Bergson,” and Vladimir Jankélévitch, “Deux Philosophes de La Vie.”

53 Bergson, The Two Sources, 16.

54 Ibid., 65.

55 Ibid., 23. For Bergson's sociobiology see, for instance, John Mullarkey, Bergson and Philosophy (Notre Dame: University of Notre Dame Press, 2000).

56 Jean-Marie Guyau, A Sketch of Morality Independent of Obligation or Sanction (London: Watts \& Co., 1898), 89.

57 Bergson, The Two Sources, 25.

58 Guyau, Sketches, 91.

59 For an assessment of Guyau's possible influence on Bergson's The Two Sources, see Renzo Ragghianti, “Décomposer un texte," 22-26. Notice that Bergson's book appeared 48 years later than Guyau’s.

60 Guyau, Sketches, 90.

61 Ibid., 5. To clarify: Guyau does not think of his work as debunking Kant's theory of the categorical imperative. He refers to it as "psychologically exact and deep as the expression of a fact of consciousness" (Sketches, 89). But he regards it as insufficient: universalization will only get us so far; after which we must, so to speak, decide on the exception. His purpose, rather, is to examine the different forces that help us become, as it were, moral sovereigns of our life.

62 Ibid., 117. More specifically, he does so as part of a reflection on the possibility of self-sacrifice in a context of moral dissolution. He asks: What could possible parallel a "duty to sacrifice oneself"? Given that, according to him, neither the categorical imperative nor hedonistic calculus will do, the question is, how can we "account for it"? The "love of risk" is an answer to this.

63 Ibid., 119.

64 That is why, for him, what economists call "risk-indifferent" would be only an artificial designation for someone who feels either ambivalent, or someone who has not had the opportunity to be properly confronted by it. But it would be misleading if we conclude that therefore he is not "summoned" by risk; he is just pulled both ways, or has not been pulled yet at all.

65 Ibid., 121.

66 Ibid., 123. My emphasis.

${ }^{67}$ See Susan Gubar, Memoir of A Debulked Woman: Enduring Ovarian Cancer (New York: W.W. Norton \& Co., 2012). She claims that a patient should not understand his or her situation as a struggle against illness, because if so you let yourself be defined by it.

68 Guyau, Sketches, 122.

${ }^{69}$ As it is also not the case that those who are risk-averse, hold such preference due to a higher valuation of their lives, as a rational-choice theorist could very well argue.

70 Notice the similarity with Bergson, regarding their respective phenomenologies of perception. See supra pp. 10-11.

Journal of French and Francophone Philosophy | Revue de la philosophie française et de langue française

Vol XXIV, No 2 (2016) | http://www.jffp.org | DOI 10.5195/jffp.2016.770 
${ }^{71}$ Guyau, Sketches, 124.

72 The exact phrase comes from a speech made by a German marshal, and quoted by Guyau, in which the former talks about the "elevated sentiment" of "knowing that the destiny of your country may depend on the orders which you give-this tension of mind and of feelings is divinely great!" (Sketches, 124).

${ }^{73}$ Guyau, Sketches, 122.

${ }^{74}$ I thank Jaime del Palacio for bringing Conrad's story to my attention.

${ }^{75}$ Guyau, Sketches, 122-24.

${ }^{76}$ Michael Sandel, "The Moral Economy of Speculation: Gambling, Finance, and the Common Good," The Tanner Lectures on Human Values (delivered at University of Utah, February 27, 2013), http://tannerlectures.utah.edu/Sandel\%20Lecture.pdf.

77|bid., 335.

$78 \mathrm{Ibid}$.

79 Sam Binkley, "The Work of Neoliberal Governmentality: Temporality and Ethical Substance in the Tale of Two Dads," Foucault Studies, 6 (2009): 61. I thank an anonymous reviewer for this specific bibliographic suggestion.

80 Ibid., 78.

81 Ibid.

${ }^{82} \mathrm{On}$ this point see, for example, Bergson, Histoire, 53-54.

${ }^{83}$ Notice that "dramatize" here refers both to the tendency to exaggerate uncertainty, and to put it into a narrative form.

${ }^{84}$ Bergson, The Two Sources, 146.

${ }^{85}$ Bergson, Histoire, 65-67. 